\title{
Impact of a Place-Based Education Curriculum on Indigenous Teacher and Students
}

\author{
Murni Sianturi \\ Musamus University, Indonesia,murni@unmus.ac.id \\ Chia-Ling Chiang \\ National Dong Hwa University, Taiwan, clchiang@gms.ndhu.edu.tw \\ Andreas Au Hurit \\ Musamus University, Indonesia, andrehurit@gmail.com
}

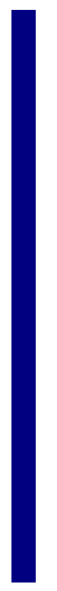

This study aimed to investigate the impact of a place-based education curriculum (PBE) on the indigenous teacher empowerment and improvement of indigenous students' learning achievement. This study applied mixed method research particularly concurrent triangulation design. The study took place in a remote indigenous elementary school in Papua, Indonesia. The participants were an indigenous teacher and eleven indigenous students. The PBE curriculum entitled "Who is Papuans" was developed by integrating the indigenous students' place. Findings of the study revealed an effective teaching for the indigenous teacher provided by developing and practicing the PBE curriculum. In order to teach indigenous students effectively, there is a need for indigenous teacher to: (a) focussing on the curriculum; (b) starting from day to day of students' life; (c) emphasizing the use of dialogs, pictures, story, writing, and telling; and (d) utilizing the cultural approach to enable students' learning achievement. By developing and practicing the PBE curriculum, indigenous teacher also obtained a new sight of culture awareness.

Keywords: curriculum, place-based education, indigenous teacher, students' learning achievement, remote indigenous elementary school

\section{INTRODUCTION}

It has been a long time, issue regarding indigenous student particularly the low learning achievement has prevailed to be a global issue (Herzog \& Pittman, 1995; Fan \& Chen, 1999; Tang, 2000; Beresford, 2001; Taipei Times, 2009; Zhang \& Sheu, 2012). There was a bias that the indigenous students kept on being underachievement students (Herzog \& Pittman, 1995; Zaini, 2010).

Citation: Sianturi, M., Chiang, C. L., \& Au Hurit, A. (2018). Impact of a Place-Based Education Curriculum on Indigenous Teacher and Students. International Journal of Instruction, 11(1), 311-328. https://doi.org/10.12973/iji.2018.11122a 
What happened with the indigenous student's learning achievement itself certainly is affected by school's curriculum and teachers. Firstly, schools took over all of educational programs practically (Dean, 2003), yet did not respect students' life characteristics (Antone, 2000). School's curriculum (Smith \& Sobel, 2010; Munroe et al., 2013) and educational materials (King \& Schielmann, 2004) were not responsive on students' need, indigenous values and native knowledge (Antone, 2000; Curnow, 2011). Also, schools focused on academic requirement but failed to integrate the culture of student in the curriculum (Smith \& Sobel, 2010).

Secondly, not only schools, at the same way teachers also focused more toward academic success rather than cultural identity of students (Stairs \& Bernhard, 2002), and pay attention to the intellects of students (Smith \& Sobel, 2010). As Lin's finding (in Lan et al., 2013) argued most of teachers always concerned on incompetence of indigenous students so accused them no spirit to raise up from weakness. The eagerness of teachers to stay in schools was dwindling (Chang \& Wang 2014). Between slumps of indigenous student academic grade and teacher's attitude might have a correlation (Tang, 2002; Lan et al., 2013).

This also occured in Indonesian schools. Although Indonesia is a multi-ethnics country, yet the government does not consider the uniqueness of each region (natural, cultural, and social wealth) to be integrated into Indonesian's school curriculum. A uniform curriculum has been implemented for all educational institutions (Rachmawati et al., 2014; Werang et al. 2014). Although, it did not reach the meaningful remote indigenous student's success (Maria, 2014). In spite of the fact that there are many factors, but this might be one of causes why most of remote indigenous schools are left behind.

As an example is in Papua, the east part of Indonesia became region with the lowest human development index in entire of Indonesia (Ministry of Domestic Affairs of Indonesia, 2013). The indigenous students in Papua has been always in the low rank. Evenmore, Kudiai (2015) stated the education as if it is trying to alienate their personal identity and leading to destruct it. They learned something that they even never see. In fact, there is a boundary between Papua students' lives and learning topics in school.

In the other hands, to solve the problems of the shortage of teachers in Papua (Ministry of Education and Culture, 2012), the government rare concerned to empower existed indigenous teachers. Most of them related to hire some temporary migrant teachersusually one year. Though, occasionally the student faces on language barrier and culture with the text book and the way of teaching of the migrant teachers.

As we know, amongs curriculum, teacher and students are affected by each other. Teachers and school's curriculum have a role in the success of students. Teachers as curriculum developers should consider an accessable and axceptable curriculum for the remote indigenous students which reach out their needs. Otherwise, teachers should master the curriculum they apply as well. Thus, a proper curriculum in such as remote indigenous elementary school needs to be considered. Place-based education (PBE) approach promotes students to connect their real life such as environment, social and culture for their future (Smith \& Sobel, 2010). A vary of studies (e.g. Emekauwa, 2004; 
Michell et al., 2008; O’Connor, 2010; Smith \& Sobel, 2010; Chiang \& Lee, 2011; Kuwahara, 2012; Scully, 2012) have revealed a positive impact of PBE on the sudents' learning achievement, but the lack of study in Indonesia dealt with educational curriculum that integrates the indigenous students' life motivates the researcher to study more on this topic.

\section{Objectives of the Study}

Considering the issues of indigenous teacher, indigenous students and educational curriculum impementing in Indonesia, it is nessesary to consider a PBE curriculum applying in remote indigenous schools. In this article we discuss how the studens' place is integrated into school's curriculum and the impacts of development and practice a PBE curriculum to indigenous teacher and student in remote indigenous elementary school in Highlands of Papua, Indonesia. Thus, the objectives of the study are two-folds. Firstly, the study focuses on the development and practice a PBE curriculum by an indigenous teacher and how it impacts to the teacher. Secondly, is to investigate the impact of the PBE curriculum to the students learning achievements. By the end of this article the readers are able to appriciate the importance of developing and practicing a proper curriculum such as PBE curriculum to the indigenous teacher and students.

\section{LITERATURE REVIEW}

PBE is an educational curriculum consists of teaching-learning activities which admires to the student's place (Eijck, 2010) and provides concepts inter-disciplines across the the curriculum by integration culture, environment, and local community (Brooke, 2003; Smith \& Sobel, 2010; Sobel, 2005). It will foster to be aware as local citizens in the future (Gruenewald, 2002; Haas \& Nachtigal, 1998; Smith \& Sobel, 2010; Sobel, 1998; 2005). PBE does not refuse the essentials of content and skills, but to make more meaningful the places to expose their engagement and understanding through multidisciplinary, experiential, and intergenerational potentially contributed to community life (Gruenewald, 2002; Haas \& Nachtigal, 1998; Smith, 2002; Theobald \& Curtiss, 2000). PBE is completely situated in place (Williams \& Semken, 2011: p.50). Here, PBE is interdisciplinary, holistic, and place integration approach of teachinglearning process, teachers'-learners' activities, situated homeschool, and individualcommunal actions.

Smith (2002) described five approaches of place-based learning that can be practiced: local culture learning, local nature learning, local internship and entrepreneurial, issuesinvestigation, problem solving and making decision in community. There is cooperation between school and community; teacher and parent; teacher and students. The students and teacher are active engaged in issues-investigation and problem solving, as a decision maker, not just a consumer, but a creator.

There are many strategies to implement PBE in schools' curriculum. Some schools integrate the unique characteristic of their environments in their curriculum. Promise of the place (2014) school names their curriculum as Chickens in the Classroom. Chickens are the most abundant animals reared in the area around the school. One of the teachers designed her lesson entitled Food Cycles in Our Community. Sobel (2005) wrote that 
there is program of school that has implemented and successfully proved which socalled Longfellow Middle School's "School on a River" program. This program implemented the river near school as their classroom and textbook. Moreover, schools integrate culture of students. In rural district in the central Australia, whereby Papunya indigenous community lives, cultural approach is the core of their education. The program of Papunya school book of country and history becomes locally applicable material. Its contents are the historical events in the community and the real-life of the society (in Bartholomaeus, 2013). Chiang \& Lee (2011) have tried to rebuild complexity of culture indigenous students in classroom. They have connected local knowledge at Huchu as node in science knowledge from Atayal, Sediq, Han Chinese, other cultures, and Western science. They have explored local knowledge traditional ways of Huchu in food reservation and ancestors' admonishment in natural disaster.

\section{METHOD}

\section{Study Design}

This present study applied mix method research. There are six procedures of mixed methods (Creswell, 2009: p. 207). This study applied one of the procedures, concurrent triangulation design procedure, which qualitative and quantitative data were gathered in same phases, but each data was analyzed separately. Although the qualitative data was exceeding than quantitative one, however the ideally the priority was equal. None was predominant to other. But they were mixed in interpretation and discussion.

The impacts of PBE curriculum toward the indigenous teaching and students were analyzed through qualitative approach (Creswell, 2009: p.4; Yin, 2011). However, the students' learning outcomes was measured through quantitative approach that was preexperimental designs (non-designs) in particular one-group pre-test-post-test design (Creswell, 2009; p.158).

\section{Participants}

The study took place at YPPGI Nokapaka Elementary School. This remote school locates in Yirene Village, Tiom Township, Lanny Jaya District. Lanny Jaya District is in central mountain of Papua, Indonesia. Here, some migrants live. But majority are Indigenous people. The participants of this study were one male indigenous teacher and eleven indigenous students.

The teacher's name is Nelius Yigibalom (pseudonym). He is a Lanninese, one of ethnics of Papuans. Papuans is a huge tribe who lives in New Guine Island (Indonesia and Papua New Guine). He was 50 years old when the study was conducted. In 1989, he completed his teacher training school, a vocational education as equivalent to a senior high school. He was not a graduate. However, in other words, he has been teaching for along enough. The researcher had a role to facilitate and empower him in developing and implementing of curriculum. The eleven students are also Lanninese. They were fifth graders. These students came from low socioeconomic status. All of them were Christians and liked to singing and dancing. Some of them live with their grandparents 
because their parents work in the city, and others passed away. At home, they always used their native language.

In the development and practicing the curriculum, some elders (one mother and one father) were also involved. Particularly, they shared their traditional knowledge of planting and conservation, local wisdom and history of their culture.

\section{Procedure}

This study was organized into three main stages which were development, implementation, and evaluation of curriculum impacts. Development of PBE curriculum was started out information about Lanny Jaya District from one informant who is an elementary teacher and lives there. Information was enriched from media such as books, Website, YouTube, online Newspaper, and Bulletins. The comprehensive description became basic information to develop preliminary curriculum.

During two weeks, getting involved to students' life from one to other students' home and interview of some elders provided clear and new understanding about the place and their live. From this, we improved the preliminary curriculum. The researcher double discussed with the indigenous teacher about the curriculum, and the teaching materials. Some revision was undertaken. After pilot study was undertaken, the final curriculum was yielded. The process of curriculum development took time five months.

Before applying the curriculum, a pretest addressed to the students. The final curriculum was applied by the teacher. When applying the curriculum, the teacher and researcher discussed how to practice the curriculum every day before his teaching. Then, we evaluated and reflected the practicing of curriculum. At the end, a posttest addressed to the students.

\section{Data Collection}

There were four data collection techniques such as observation, interview, test, and documentation. Either observation or interview was used to gather data during develompent, practicing and evaluation of curriculum impacts. A systematical observation particularly was undertaken during the development of curriculum, teaching and learning process in order to obtain how the teacher implemented and student learned by using PBE curriculum. The interview consisted of unstructured and semi structured interview. Unstructured interview was undertaken in order to gain information regarding teacher's perception about students' learning difficulty in term of unconnected between school and place and why he believed that the curriculum can provide him to solve the difficulty; and how the teacher practice the PBE curriculum. Semi structured interview was to gather information in development of curriculum and data of teaching experience on PBE curriculum.

The curriculum impact of academic outcomes was measured by test. The test was multiple choices type and consists of eight items, developed in bilingual (Indonesian and Lanninese). Items form story containing of literacy, science, and mathematics problems about student's place. This research also took private document such as students' worksheet and audio-visual materials to gain data in regard progress of student learning. 


\section{Data Analysis}

The raw qualitative data was collected from field move to deeper and deeper senses out, and analyzed through interpretation of the larger meaning of data. Meanwhile, the quantitative data was analyzed by using descriptive statistics and one sample means test of non-parametric statistic which was Wilcoxon Signed Ranked Test approach. The small sample size is better to be analyzed by non-parametric statistic (Bernard, 2000). The whole results, either qualitative or quantitative analysis were compared and connected and then it yielded some discussion and conclusion.

\section{FINDINGS}

The impacts of PBE curriculum were organized into two parts such as the impact to the teacher and students. The impact to the teacher emphasized to the teaching by implementation of the curriculum. While, the impact to the students emphasized their learning achievement.

\section{Teaching by Implementation of PBE Curriculum}

The PBE curriculum entitled "Who is Papuans" was developed by integrating the students' place which comprised of culture, environment and social circumtances. The curriculum using billingual, Indonesian-Lanninese. The description of the PBE curriculum is provided in the appendix 1. Practicing this curriculum provided an effective teaching for the teacher and a new sign of culture awareness.

\section{a. An effective teaching}

In order to teach indigenous students effectively, there is a need for indigenous teacher to: focussing on the curriculum; starting from day to day of students' life; emphasizing the use of dialogs, pictures, story, writing, and telling; and utilizing the cultural approach to enable students' learning achivement.

\section{The first was focusing on the curriculum.}

With referencing to the lesson plans were prepared within the curriculum facilitated him to focused on the learning expectation. Lesson plans were very helpful to his teaching. He commended, "Sometimes when I forget the next topic or teaching steps, I back to the curriculum.... Afterward, I am able to continue my teaching."

Through the curriculum itself the teacher was able to imagine a frame that would occur during the learning. Every one week afore the class was going, he relearned and then discussed the curriculum with the researcher to ensure that he had prepared everything he need.

\section{The second was starting from the day to day of student's life.}

Taking advantage from students' life as learning discussion was a simple strategy yet yielded immense effects. Such as singing and praying were activities almost every day the students did. At the beginning and end of class, pointing out one student alternately to lead a pray and a song became one of his teaching strategies.

To deliver students on the topic "read a clock", the teacher utilized the students' daily routines. Every morning they came to school without looking at the clock. They only 
perceived from the presence of the sun. When the sun had started to rise, they would go to the school. They sticked to the habits of their parents every day. This is why some of their parents didn't provide a clock in their house. As a consequence, when wheather was cloudy some of the students occasionally came late.

Reading a clock is important to help them in doing their activities. However, it was difficult to give this understanding. In addition, the students never questioned 'why' their parents applied the sun as a tool to measure time.

Therefore, through learning in school, respectively the students were assigned to ask their parents. More specifically, the teacher equipped the students with personal tracking how the sun position in the morning, noon and afternoon. They recorded some daily routines and categorized them into normally undertaken every morning, noon, and evening. In the morning afore going to school they had to determine the sun position and revisit after arriving at school. For those whose a clock at their home, the teacher asked them to draw the clock and the position of clock hands. Likewise, the teacher could directly teach how to read a clock and measure time in subsequent meetings. From this learning, the students finally understood why the sun position used as a sundial, and what the benefit of the clock to help them measure time exactly.

He found that by connecting students' life to learning topics and as much as possible to make it as a learning topic, he could attracted the attention of students. Then, the students gradually considered the benefit of topics they learned.

The third was emphasizing on dialogues, pictures, story writing, and telling with billingual.

At the beginning, when he asked some questions, most of the students shamed and hesitate to argue. It might be caused they seldom practiced to speak out in public by using Indonesian. However, teaching by dialogues with bilingual enabled the teacher to encourage them. Consequently, they master the lessons easier. The teacher kept in dialogues to improve the students' bravery. He continued to ask them one by one. If one student to whom the teacher gave question in Indonesian felt confuse, the teacher switched the question into Lanninese. Afterward the student understood the teacher question, the student continued to share his/her opinion.

Although the students have not read as fluent as the fifth urban students generally, however they felt challenges when faced reading matters. At the first week, the teacher shared a picture story book and the students stimulated it full-curiously. They adored the pictures, because they knew the children within the pictures as well as the children's activities were representation of their activities. The children in the pictures were their seniors and friends. Applying roles playing was set up outside of the school, through picture script provided them to more expressive to talk in front of their classmates.

At the fourth week, the teacher gave some pieces of picture (all the pictures related to their culture). The teacher asked, "What do you see?" The students would be enthusiastic to share their opinion. Almost all students gave their idea, and rarely did they speak out in full of Indonesia. Shortly after that, the teacher asked the students to 
create a simple story from each picture. Even though some students took same pictures, however they had different views of their writing.

The fourth was utilizing culture approach to enable students' learning achievement.

The conversations about cultures as if restored his memory when he used to attend school. "Spirit of our culture such as call back," was how he explained his enthusiasm for local culture pour out in learning. The following was a fragment of his teaching.

The teacher: "... In the past, when war was coming our ancestors used spears, whilst enemies were close. However, if the opponent is away, may not use spears?"

Some students: "Impossible"

The teacher: "Unless wear? What is it?"

Some students: "Bow and Arrows"

The teacher: "Yes, those are. But why can those?" (the students are whispering to find out)

The teacher: "Because using arrows that there is power here (pointing bowstring). That's why it is able to rebound away when release. Try to remember, boys usually looking for birds in the forest. The bird would not close. Usually birds where? Huh, above all, on big and high trees. But the boys shoot from here. The trick is not like this, but it's like this. He began measuring with their eyes (he demonstrated, bows and arrows directed upwards), from here he started to pull... Up? What? ... Release!"

A fragment of storytelling combined with some dialogues above showed how the past history connected with the present lives of children. The questions posed by the teacher were answered by the students with enthusiasm. The teacher confirmed the benefit of archery for our health recently. He also told that not only indigenous people applied it, but recently archery is one of sports.

When the students practiced archery (as shown in figure 1), the teacher explained, "If you want to practice archery, put the notched end of the arrow is adhered against the bowstring, with the pointed head extending beyond the bow. Then, with your one hand, left or right one chocks against the bow and the other one grips the string, you pull back on the string. There is a power storing in the bow, it names potential energy. When you release the string, the potential energy is converted to another power named kinetic energy. Then, it is imparted to the arrow, forcing it forward suddenly and rapidly."

The teacher's question about "why arrows could rebound much higher than the spears" was a scientific question what referred to the thinking of students. The teacher explained it by: comparing mass of arrow and spear respectively, with analogy of trhrowing a small stone and big one; and also the measure of angle.

In the footage above, the learning process continued with the understanding of the concept of angle in theoretically. Practicing archery became a committed approach to relief students' knowledge. "Perhaps this does not only support them to learn, but it presents an opportunity to recall what is commonly done by their father. I feel that it's an activity that gives room to realize how precious these cultures are," the teacher strongly testimony. 
On another occasion, a female elder was invited to contribute in the class at second week with the theme "noken is my best bag" (as shown in figure 2). The students were entrusted to interview all matters related to noken. The Student alternated turns asking questions. After an explanation of the mother, several students would be asking another question, one question continued to connect to other questions. This cultural approach facilitated the students to develop their curiosity.



Figure 1. The students are shooting by using traditional bow and arrows.

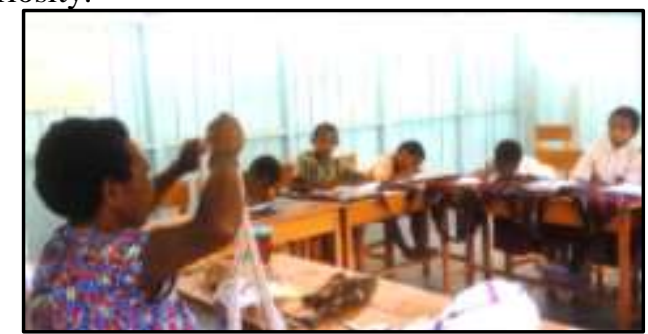

Figure 2. A female elder is telling the students about noken

The dialogue of mathematical tasks (as provided in appendix 2), as interdisciplinary communications in teaching was an example of sticking student's culture enabled them to understand the teacher's explanation. Rolling of the examples, the teacher was equipped to provide materials of factoring and the greatest common factor.

\section{b. A new Sight of Culture Awareness}

Adopting a place-based frame as a reference and ensuring that principles of PBE curriculum within entire lesson plans challenged the teacher. The PBE curriculum was a very new for him and it was certainly not easy and required him to learn a lot. A numerous time should be devoted to discuss it with the researcher. His previous teaching experiences focused to teach the students in literacy and numeracy without having any goals of each meeting, but now the teacher had to teach using more detailed curriculum rendered him more thoroughly. Learning outcomes was designed based on the big frame and not specific would obscure every essence of teaching. A habit of teaching which was not based on specific goals would yield teaching to walk lightly. As the teacher described,

"... We, teachers in remote areas, focus merely on teaching students to read and count. I do not need to make a plan as detail as this.... If students have started to read, then we will move forward to the numeracy... Although I have to follow the national curriculum training, I do not know how to put them in my teaching."

Although at the beginning the teacher had given plenty of time to be able to grasp the concept of thinking of this place-based approach, in the end he appeared appreciation and gratitude for having the opportunity to learn and apply this model. He realized that, integrating the students' culture into the curriculum was important. Culture is as indigenous people identity never included before, became a real image of the teacher's teaching. Not just the impact on himself, yet especially since the teacher paid attention to the given response of the students. The teacher admitted, 
"Regardless of the lack of teachers, place-based approach comes up a lot of positive things from students which are often overlooked... I see the children are very happy to learn. I appreciate then of their changes in terms of enthusiasm. The students are not shy anymore to answer, even if their answers sometimes are wrong."

As he recalled, this kind of learning has never been applied in schools. Even if there was local content, it was only a crafting. The teacher commended this learning revealed of the positive attitude of the students, fostered their appreciation to their land and culture, and also facilitated to dig their ability of literacy and numeracy. He acknowledged that the teaching that has been implemented was to enable the process of students' understanding. Overall, the teacher enjoyed the teaching by implementation of PBE curriculum. The teacher stated local materials were very necessary to develop even more in teaching. The new sight of culture awareness he gained was far more valuable rather than challenges he underwent.

\section{Student Learning Achievement}

The implementation of the curriculum affected to the teacher's teaching and, in turn, affected students' learning achievement. The students learning achievement in this study included not only academic but also writing skill and confidence.

\section{The Student's Academic Outcomes}

The student academic outcomes was shown of the results of score between pretest and posttest. It is provided in table 1 below.

Table 1

Analysis of Mean Score between Pretest and Posttest

\begin{tabular}{lllll}
\hline & $\mathrm{N}$ & Mean & $\mathrm{Z}^{*}$ & Asymp. Sig. (2-tailed) \\
\hline Pretest & 11 & 27.27 & -2.675 & 0.007 \\
Posttest & 11 & 65.91 & & \\
\hline$* .95 \%$ & & &
\end{tabular}

*: $95 \%$ confidence interval

The mean score between pretest and posttest was significantly increased from 26.27 become 65.91 , there was 39.64 point increasing. According to the Wilcoxon Signed Ranked Test value of $\mathrm{Z}_{(.05 ; 10)}=-2.675 ; \mathrm{p}=.007$ is less than $\alpha$ level, .05. This presents that score at pretest was significantly different with score at posttest. Therefore, it concluded that the students' learning outcomes was significantly increased.

\section{The Student's Writing Skill}

The student's writing skill also increased. It was shown in one of the student worksheets provided in appendix 3. In part (i) at the first week, the students were asked to write down their daily activities. In part (ii), at fifth week the students were given a picture and asked them to write the story of the picture. Although this assignment different each other, but basically the main idea was to write a story. Part (i), students were only required to write what they have experienced. In other words, students only involved their experience. While part (ii), to develop a story based on the picture. In part (ii), indirectly the students would build connections between what they saw in the picture 
with what they experienced (due to the burning stone event itself surely they have done in their place).

In part (i), the student combined multiple activities in a single line. As a result, if the readers were not careful, they would be confusing in the meaning. Here, in the terms of punctuation, the student was still lacking. Compared with part (ii), the student started to pour ideas in a logical and orderly. The student also was able to begin to use punctuation correctly.

\section{The Student's Confidence}

Some of the students' habits when were asked to give opinion or speak in front of people were smiling, covering their face, biding hands, sticking out tongue, and having head down. In this curriculum, dialogue and presentations were structured to foster their confidence. They slight experienced changes. In the fourth week, with the theme Nothing Compares with $\mathrm{Bi}$, before class, the students were asked to inquire about $b i$ with their parents each to know more information. Then they had to deliver it, by holding a potato while storytelling. In this moment, they had already begun to dare to look ahead their classmates. Thus, it concluded that the learning outcomes, skills or other behaviors of students increased by implementing PBE academic curriculum.

\section{DISCUSSION}

A lot of discourses raise up between indigenous knowledge and western one (Brigg, 2016). Brigg (2016) argued that rather than staying with an understanding, between who is important and not, the linkage becomes possible to integrate indigenous knowledge. Based on the results of study showed that application of PBE curriculum give positive impact on both of teacher and students. Basically, the developed curriculum ipplied local-based approach. The design of curriculum integrated to the culture and environment context enabled the native teacher to see more clearly the meaning of teaching. As Weuffen et al., (2016) recommended a discourse in regards providing teachers a critical thinking how to approach their education practices through indigenous histories and cultures as well as recent studies have recommended to Mathematics, and English teachers to apply PBE in their instruction (in Barratt \& Hacking, 2011). Also, Lee's \& Chiang's findings (2011) revealed advancements in elementary teacher development by designing and applying science instructional curriculum of PBE for indigenous students. Sharing cultural matters to promote the reading, writing, numeracy, and science was easier than solely the reading, writing, numeracy, and science themselves. Regardless, this process has brought teacher to be aware of the importance of developing and embodying local things into the teaching process. Actually, Sharif \& Gisbert (2015) also argued amongst culture, values, teaching and learning there was a bon one each other's. Even in a number of articles analyzed by Locke \& Prentice (2016) there were much talk how music teachers became more sensitive and critical to indigenous culture and music context.

When the students faced difficulties in understanding of the material, the presence of the native teacher was extremely essential to explain it by using bilingual of instruction. Nee-Benham \& Cooper (2000) also suggested that the importance of the use of local 
languages in the learning process, especially for basic education. The roles of native teacher are also more visible because he himself is a person who understands the culture and conditions of their place. Simultaneously, he could be a clear example to the students in the process of planting the identity of the student. Also additional, native teachers can also be a bridge between the local communities (elders) to school. In this study, using place-based approach had an impact on student learning achievement. Learning outcomes such as academic outcomes and other capabilities increased. Several studies (Emekauwa, 2004; O'Connor, 2010; Yen et al., 2013) also have shown that PBE give impacts in enhancing student science learning achievement. In Barratt \& Hacking (2011), a study was investigated by Howley shown that learning through the place gave impact on student mathematics learning. Similarly, an English lessons place-integrated approach was examined by Coleman improved male student's writing skills.

Regardless of student academic outcomes, the application of PBE brought learning as closely as possible to living. After the implementation of this curriculum, the confidence of children also increased. In this case the confidence is when students can boldly express their opinions either in writing or orally. This increased confidence perhaps because the topics discussed were close to them so they feel no doubt if later on they would make mistakes. Distrust usually arises because of ignorance of what is delivered. They also were interesest at indigenous knowledge and

Their life was presented in the form of learning not only stimulated their enthusiasm for learning. They were engaged in whole process of learning. Linked school-home activities provided them to attend schooling very often. Likewise, failure and disengagement amongst Indigenous students was successfully reduced through an experimental program by modeling a holistic education of substance of place and local knowledge (O'Connor, 2010). Barratt \& Hacking (2011) reported some examples PBE success in UK such as Gayford's WWF-Funded research in 15 schools in the UK (2009) revealed that providing students' space to contribute actively fostered learning as closely as possible to living, and getting close between their real-world contexts and local issues. Percy-Smith's (2009) Economic and Social Research Council (ESRC)-funded research that student-engagement learning mastered young learners in greatest effect on learning.

\section{CONCLUSION}

The development and implementation of PBE curriculum in one of the remote elementary schools in Highland of Papua, Lanny Jaya provides an effective education. The students could understand the lesson easily because the adopted approaches rooted into the context of their daily lives. The curriculum entitled "Who is Papuans?" in which applies a bilingual instruction by the indigenous teacher reduces the phenomenon of language barrier between teacher and students which happened for many years. Using the native language and national language at the same time in the learning process eases the student to master the lessons. Through learning as closely as possible to living, the students are more confident to express their opinion, students' writing skill improved as well their learning outcomes. 
Also, this curriculum facilitates the teacher in the teaching. A new teaching experience makes the teacher is easy to improve the student's reading and math. It also provides learning for himself how to resolve the students' difficulties that has been experienced. A new perspective about teaching in particular such as isolated remote area approaches the teacher. There is more passion. There is in-depth understanding how precious culture and student's life to be integrated in school's curriculum. In this study is found that the existence of the indigenous teacher impacts and enables in developing and practicing this curriculum.

This study suggests the district government to consider a local based curriculum; it means that the system and program should ground to the student's place characteristics. The government should be sensitive to culture, life, and environment as an integration of educational approach. If government implements a local-based curriculum, it has to concern on the success locally as well. When the local-based curriculum applied, the government could deem to create local-based textbooks. The textbooks should contain a lot of local attributes such as customs, local wisdom and knowledge, specific environment, other student's place properties. Also, it should emphasize images of the real environment and of people living in the place. Despite of native teachers who actively teach are very few, but as the results of this study were, that the local teacher's role is indispensable particularly in the time of students reaching out primary education. The government may be able to figure out how to empower and enable native teachers were already there. On the other hand, if the hiring of migrant teachers is a priority, perhaps the teachers could be accommodated to teach at a higher level. However, it can be sure that teachers are equipped with local knowledge, in order to adapt in their teaching. Also, it may be better if the bilingual is applied in the formal school. Beside of is useful as the language of instruction which facilitate communication and learning, the using bilingual instruction becomes one way in order to local languages are not extinct in formal education. It will support the students to maintain their culture identity and preparing them in Indonesia society as their nationality. Thus, teachers in Indonesia particularly the teacher to whom the researcher collaborated with may obtain some new sights in terms of teaching development. The teacher may consider such as PBE instructional design becomes a guideline in his lesson plans. Also, teachers of other countries have a quite similar circumstance in the context of remote indigenous education may take benefits in their teaching along with the findings of the study to support their remote indigenous students. This may provide a new persfective of integrating students' place for global's readers.

The time short of discussion with the teacher led some incomprehensive understanding of PBE. More ethnographic data would make the curriculum more local. Thus, more discussions with some elders or local community previously would give them more understanding of participatory in this research. Since this study was preliminary research in developing and implementation of PBE curriculum in Papua, in the future investigation it may conduct a study on developing and implementation of PBE curriculum in different topics, grades and levels such as middle or senior high level. It is possible to discover a place-project research that engages local community. 
Furthermore, to investigate the effect of books developed by integrating the student's place how it will enable the student to read, write, and count in very basic level.

\section{REFERENCES}

Antone, E. (2000). Empowering indigenous voice in indigenous education. Canadian Journal of Native Education, 24(2), 92-101.

Barratt, R., \& Hacking B. E. (2011). Place-based education and practice: Observations from the field. Children, Youth and Environment, 21(1), 1-13.

Bartholomaeus, P. (2013). Place-based education and Australian curriculum. Literacy Learning: the Middle Years, 21(3), 17-23.

Beresford, Q. (2001). Policy and performance: Indigenous education in Western Australia in the 1990s'. Australian Journal of Education, 45(1), 23-34.

Bernard, H. R. (2000). Social research methods: Qualitative and quantitative approaches. California: SAGE Publications, Inc.

Brigg, M. (2016). Engage indigenous knowledges: From sovereign to relational knowers. The Australian Journal of Indigenous Education, 45(2), 152-158.

Brooke, R. (2003). Rural voices: Place-conscious education and teaching of writing. New York: Teachers College Press \& National Writing Project.

Chang, C. N., \& Wang, L. Y. (2014). The influence of family and school factors on student achievement in rural Taiwan. Presented in ECER 2014, The Past, the Present and the Future of Educational Research, European Educational Research Association. Retrieved November 15, 2014 from: http://eera-ecer.de/ecer-rogrammes/conference/19/ contribution/30863/.

Chiang, C. L., \& Lee, H. (2011). Whose science? Whose curriculum? Local knowledge as a node in science knowledge networks. Presented in $11^{\text {th }}$ International IHPST and $6^{\text {th }}$ Greek History, Philosophy and Science Teaching Joint Conference, 1-5 July 2011, ThessalonikiGreece, 1-4.

Chou, H. M. (2005). Educating urban indigenous students in Taiwan: Six teachers' perspectives. Doctoral' Dissertation (Unpublished). p. 1-322.

Creswell, J. W. (2009). Research Design: Qualitative, Quantitative, and Mixed Methods Approaches. California: SAGE Publications, Inc.

Curnow, P. (2011). Indigenous skies. Australian Science, 32(8), 22-25.

Dean, B. (2003). Indigenous education and the prospects for cultural survival. Cultural Survival. Retrivied November 10, 2014 from : http://www.culturalsurvival.org/.

Eijck, M. (2010). Place-based (science) education: Something is happening here. Cultural Studies and Environmentalism, in D.J Tippins et al. (eds.), Cultural Studies and Environmentlism, Cultural Studies of Science Education Vol.3, doi: 10.1007.

Emekauwa, E. (2004). The star with my name: The Alaska rural systemic initiative and the impact of place-based education on native student's achievement. The Rural School and Community Trust, 1-10.

Fan, X., \& Chen, M. J. (1999). Academic achievement of rural school students: A multi-year comparison with their peers in suburban and urban schools. Journal of Research Education, 15(1), 31-46. 
Gruenewald, D. (2002). Teaching and learning with Thoreau: Honoring critique, experimentation, wholeness, and the places where we live. Harvard Educational Review, 72(4), 515-541.

Haas, T., \& Nachtigal, P. (1998). Place value. Charleston, WV: ERIC Press.Smith, G. (2002). Place-based education: Learning to be where we are. Phi Delta Kappan, 83, 584-594.

Herzog, M. L. R., \& Pittman, R. B. (1995). Home, family, and community. Ingredients on the rural education equation. Phi Delta Kappan, 77, 113-118.

King, L., \& Schielmann, S. (2004). The Challenge of Indigenous Education Practice and Persfectives. Paris: UNESCO Publishing.

Kudiai, M. (2015). Pemekaran dan Proses Pemusnahan Manusia Papua Melalui Pendidikan. Indoprogress News, $4^{\text {th }}$ June 2015. Retrivied June 4, 2015 from: http:// indoprogress.com/penulis/mikael-kudiai/.

Kuwahara, J. L. H. (2012). Impacts of a place-based science curriculum on students' place attachment in Hawaiian and Western cultural institutions at an urban high school in Hawai'i. International Journal Science and Mathematics Education, 11, 191-212.

Kyle, G. T., Mowen, A. J., \& Tarrant, M. (2004). Linking place preferences with place meaning: An examination of the relationship between place motivation and place attachment. Journal of Environmental Psychology, 24, 439-454.

Lan, C. J., Liu, R. L., \& Hsu, L. M. (2013). The study of learning of college nursing aboriginal students in Taiwan-combine both longitudinal and cross-sectional methods. Journal of Modern Education Review, 3(8), 587-603.

Locke, T., \& Prentice, L. (2016). Facing the Indigenous 'Other': Culturally Responsive Research and Pedagogy in Music Education. The Australian Journal of Indigenous Education, 45(2), 139-151.

Maria, D. (2014). Pemenuhan pendidikan di daerah terdepan, terpencil dan tertinggal. Kompasiana News, $4^{\text {th }}$ April 2014. Retrivied April 4, 2014 from:http://kompasiana.com/.

Michell, H., Vizina, Y., Augustus, C., \& Sawyer J. (2008). Learning Indigenous Science from Place. Canada: College of Education University of Saskatchewan.

Ministry of Domestic Affairs of Indonesia. (2013). APBD tinggi, pembangunan rendah. Retrivied May 10, 2015 from: http://otda.kemendagri.go.id/index.php/berita-210/631-apbdtinggi-pembangunan-rendah.

Ministry of Education and Culture. (2012). Maju bersama mencerdaskan Indonesia. Retrivied June 23, 2015 from: http://dikti.go.id/.

Munroe, E. A., Borden, L. L., Orr, A. M., Toney, D., \& Meader, J. (2013). Decolonizing indigenous education in the $21^{\text {st }}$ century. McGills Journal of Education, 48(2), 317- 337.

Nee-Benham, M. K. P., \& Cooper, J. E. (2000). Indigenous Educational models for Contemporary Practice: In our Mother's Voice. U. S. A: Lawrence Erlbaum Associates Inc.

O'Connor, K. (2010). Experiential Learning in an Indigenous Context: Integration of Place, Experience and Criticality in Educational Practice. Canada: Canadian Council on Learning. 
Promise of the Place. (2014). Chickens in the Classroom: A Lesson in Multi-Ethnic Placebased Education. Retrieved March 13, 2015 from: http://promiseofplace.org/ Stories_from_the_Field/Display?id=7.

Rachmawati, Y., Pai, Y. F., \& Chen, H. H. (2014). The necessity of multicultural education in Indonesia. International Journal of Education and Research, 2(10), 317-328.

Scully, A. (2012). Decolonization, re-inhabitation and reconciliation: Indigenous and placebased education. Canadian Journal of Environmental Education, 17, 148-158.

Sharif, A., \& Gisber, M. (2015). The Impact of Culture on Instructional Design and Quality. International Journal of Instruction, 8(1), 143-156.

Smith, G. A. (2002). Place-based education: Learning to be where we are. Phi Delta Kappan, $83,584-594$.

Smith, G. A., \& Sobel, D. (2010). Place- and community-based education in school. New York: Routledge.

Sobel, D. (1998). Mapmaking with children: Sense of place education for the elementary years. U. S. A: Heinemann.

Sobel, D. (2005). Place- based education: Connected classrooms and communities. U. S. A: The Orion Society's Nature Literacy Series.

Stairs, A. H., \& Bernhard, J. K. (2002). Considerations for evaluating "good care" in Canadian indigenous early childhood settings. McGills Journal of Education, 37(3), 309- 331.

Taipei Times. (2009). The urban-rural gap in education. Retrieved November 25, 2014 from: http://www.taipeitimes.com/News/editorials/archives/2009/07/19/2003449021.

Tang, G. D. (2000). A review and prospects of educational revolution of aborigines. Indigenous Culture and Education Communications, (5), 5-11.

Tang, G. D. (2002). A longitudinal study of adaptation and loss issues of indigenous junior high school students. Report of Special Subject Plan by National Science Council: NSC 902413-H-003-005.

Theobald, P., \& Curtiss, J. (2000). Communities as curricula. Forum for Applied Research and Public Policy, 15(1), 106-111.

Weuffen, S., Cahir, F., \& Zeegers, M. (2016). What's in a name? Exploring the implications of Eurocentric (re)naming practices of Aboriginal and Torres Strait Islander nomenclature in Australian education practices. The Australian Journal of Indigenous Education, 45(2), 181-190.

Williams, D., \& Semken, S. (2011). Ethnographic methods in analysis of place-based geosciences curriculum and pedagogy, in Feig, A. D., and Stokes, A. (Eds.), Qualitative Inquiry in Geoscience Education Research: Geological Society of America Special Paper 474; p. 49-62, doi: 10. 1130/2011.2474(05).

Yen, C., Yao, T., Lee, H., \& Chiang, C. (2013). The effect of indigenous elementary students' place-based science instruction in Taiwan: learning efficiency and ethnic identity. NARST, 1-8.

Yin, R. K. (2011). Qualitative research from start to finish. New York, NY: Guilford. 
Zaini, A. H. F. (2010). Pembangunan pedesaan. Kementrian Desa, Pembangunan Daerah Tertinggal dan Transmigrasi, 1-2. Retrieved November 14, 2014 from: http:// kemendesa.go.id/.

Zhang, L. C., \& Sheu, T. M. (2012). Effective Investment strategies on mathematics performance in rural area. Science and Business Media, Springer, 1-19, doi: $10.1007 / \mathrm{s} 11135-012-9752-\mathrm{x}$.

\section{Appendices}

Appendix 1. PBE Curriculum

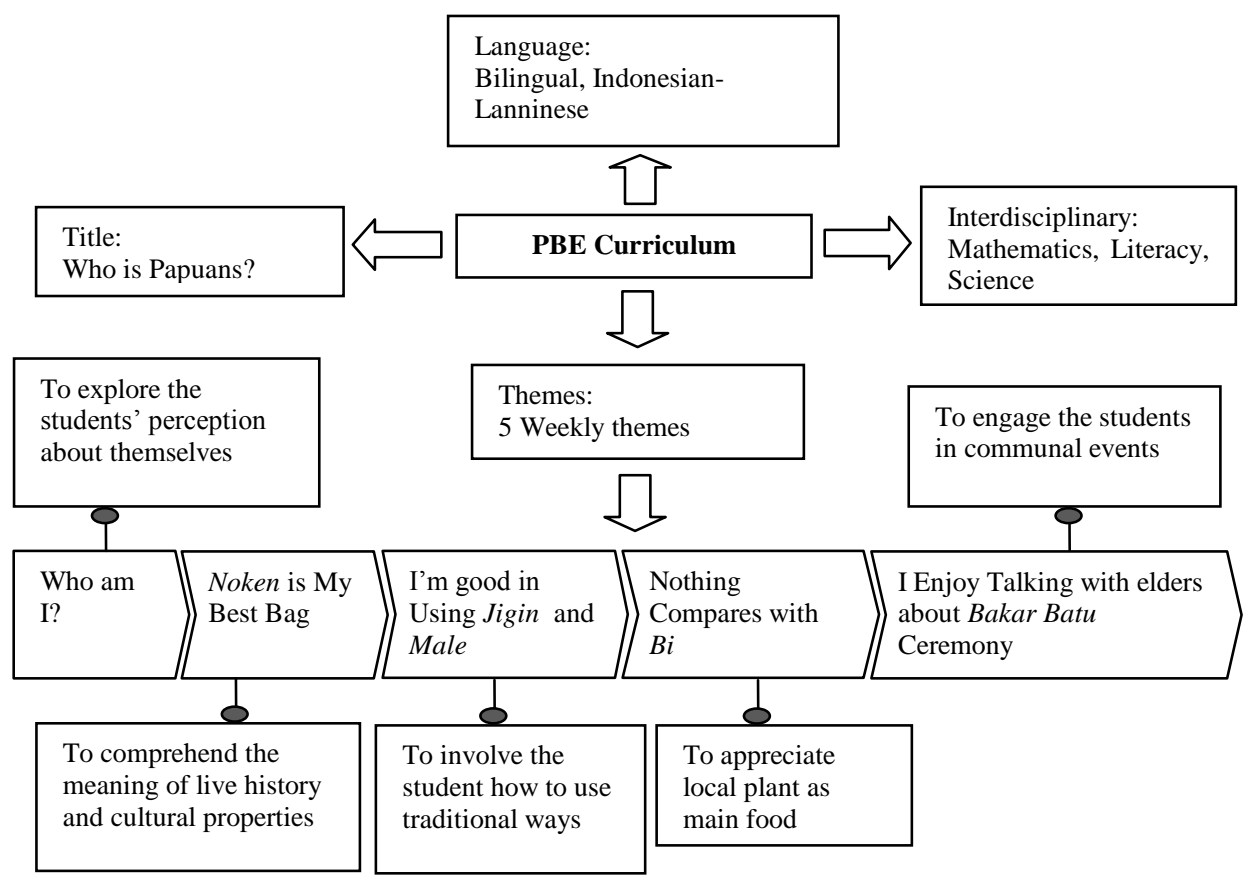

Figure 3

PBE curriculum and its characteristic

The curriculum was a formal educational curriculum. It was developed by consideration the school's syllabus. This curriculum was not a "muatan local" curriculum as it was known in Indonesia, which usually takes several topics of local knowledge as one of the subjects commonly called "muatan local" subject. In the sense in accordance with the content, this curriculum was not only contextual teaching-learning (CTL). This curriculum integrated the culture, local wisdom, and things relate to the surrounding area as the main point to educate students not only in one particular skill, but covered all the achievements that might be obtained by students. This curriculum turned out to real life those students to give them room to discuss even to practice directly in schools. 
This curriculum entitled "Who is Papuans?" because the curriculum is not only focused on improving student learning achievement, but also to teach the students "who really they are as the Papuans". The teacher used bilingual, Lanninese-Indonesian during learning activities particularly when the students found difficulty, teacher used the local language. The teacher would use it to present new Indonesian words or expressions and describe each meaning. Meanwhile students could use Lanninese-Indonesian to talk about literacy and numeracy.

Some materials used during learning were a picture book entitled "Getting to know the daily life of children in Papua, Lanny Jaya", noken (traditional bag), bi (sweet potatoes, as the Lanninese main food), jigin (bow) and male (arrows), colorful cards, traditional songs, and materials for bakar batu ceremony (one of traditional ceremonies by burning stone) such as sali (a kind of traditional skirt), koteka (penis sheath of Papuans), bingga (a kind of vegetables), kolengga (a kind of vegetables). Each material was matched according to themes. Class was set by student center activities. The approaches taken were quite varied, with a group discussion, interview, writing a story, creating objects, singing, presentations the results in front of the class, storytelling, questioning and dialogue and playing game. For instance, students interviewed some elders, write the interview results and their reflection, discuss in their group, create, and perform simple theaters (stories) as their appreciation of their culture. The teacher would invite some elders to come to school to teach the students regarding noken and how to use bow and arrows. The teacher and the students with elders would celebrate a simple bakar batu ceremony in school.

Appendix 2. The transcript of teacher and students dialogue about noken

The teacher : "There are fifteen noken containing potatoes. It will be taken at the burning

Student 10 : "Fifteen people"

Student 2 : "Five people"

The teacher : "If five persons will bring noken, how many noken for each person?"

Some students: "Three"

The teacher : "Eih.. Someone said, "There are fifteen noken, five people let's go! He knew that one person took three noken." and so on)

(the teacher continued to other examples if twenty, nine

Appendix 3. Worksheets of one student regarding story writing

Daily activities

Waking up. Praying (morning)

Helping mother washing dishes (morning)

Roasted sweet potato digging sweet potato

(morning)

Cooking rice going to school (morning)

keeping brother playing taking bath

(afternoon)

Eating potato Going bed (evening)
Bakar Batu Ceremony in the yard

There are 3 houses. There are some mothers are taking the stone. There are few fathers are taking the stone. These mothers are holding wood for cooking bingga, cooking, cooking potatoes, cooking corn, and cooking kolengga. The mothers are wearing sali. The fathers are wearing koteka. The fathers never wear sali. The mothers also never wear koteka. The mothers are wearing noken on the head.

ii 